\title{
End stage renal disease in French Guiana (data from R.E.I.N registry): South American or French?
}

\author{
Dévi Rita Rochemont ${ }^{1 *}$, Mohamed Meddeb², Raoul Roura ${ }^{3}$, Cécile Couchoud ${ }^{4}$, Mathieu Nacher ${ }^{1,5}$ \\ and Célia Basurko ${ }^{1,5}$
}

\begin{abstract}
Background: End-Stage renal disease (ESRD) causes considerable morbidity and mortality, and significantly alters patients' quality of life. There are very few published data on this problem in the French Overseas territories. The development of a registry on end stage renal disease in French Guiana in 2011 allowed to describe the magnitude of this problem in the region for the first time.

Methods: Using data from the French Renal Epidemiology and Information Network registry (R.E.I.N). Descriptive statistics on quantitative and qualitative variables in the registry were performed on prevalent cases and incident cases in 2011, 2012 and 2013.

Results: French Guiana has one of the highest ESRD prevalence and incidence in France. The two main causes of ESRD were hypertensive and diabetic nephropathies. The French Guianese population had a different demographic profile (younger, more women, more migrants) than in mainland France. Most patients had at least one comorbidity, predominantly (95.3\%) hypertension. In French Guiana dialysis was initiated in emergency for $71.3 \%$ of patients versus $33 \%$ in France $(p<0.001)$.

Conclusion: These first results give important public health information: i) End stage renal disease has a very high prevalence relative to mainland France ii) Patients have a different demographic profile and enter care late in the course of their renal disease. These data are closer to what is observed in the Caribbean or in Latin America than in Mainland France.
\end{abstract}

Keywords: Co-morbidities, Epidemiology, French Guiana, Incidence, Prevalence, End stage renal failure

\section{Background}

The irreversible alteration of renal function leads to chronic renal failure which may reach a end stage requiring dialysis for the patient to survive. It is estimated that nearly 1 in 100 persons is suffering from renal failure, among whom $0.13 \%$ have end stage renal disease (ESRD) [1]. In France, 37,430 persons underwent dialysis in 2010 and 29,841 received a kidney transplant.

ESRD is both a consequence and an aggravating factor of a number of cardiovascular and metabolic pathologies.

\footnotetext{
* Correspondence: devi.rochemont@ch-cayenne.fr

${ }^{1}$ Centre d'Investigation Clinique Epidémiologie Clinique Antilles Guyane CIC INSERM 1424, Centre hospitalier Andrée Rosemon, Rue des flamboyants BP 6006, 97306 Cayenne, French Guiana

Full list of author information is available at the end of the article
}

It is associated with a considerable increase in morbidity and mortality, and significantly alters the patients' quality of life [2]. In Mainland France and in Latin America, the 2 main reported causes of renal failure were, for over half of patients, diabetes mellitus and high blood pressure [3-5]. The increase of the incidence of these 2 pathologies raises the concern that the prevalence of chronic renal failure will increase in years to come.

In French Guiana, a French territory in South America between Brazil and Surinam, diabetes mellitus, which is probably underestimated, has increased by $57 \%$ between 2004 and 2007 [6]. The prevalence of high blood pressure in the French Caribbean and in French Guiana has been estimated at $18,9 \%$ for women, versus $9,3 \%$ in mainland France [7]. The frequency of stroke, the first 
cause of death in French Guiana, also reflects the problem represented by these pathologies in the Caribbean and in French Guiana. Mortality from stroke was 77.9\% higher among men and $22.5 \%$ among women when compared to the national average [8].

There are few available data on renal failure in the French overseas territories of America. According to the literature, one in every three diabetic patients develops renal failure after 10 years of diabetes mellitus (6\% having end stage renal disease) [9]. In addition French Guiana still has an important burden of infectious diseases notably HIV (Human Immunodeficiency Virus), which in itself, or through nephrotoxic treatments, can cause renal failure $[10,11]$. French Guiana is also marked by socioeconomic differences which can lead to health inequalities regarding access to care. Thus, given the prevalence of metabolic and cardiovascular problems in French Guiana, it is important to better understand the profile of patients with ESRD in order to slow down or prevent the occurrence of this complication. The objective of the present study was to describe the epidemiology of ESRD in French Guiana and compare it to mainland France.

French Guiana has very specific geographic and demographic characteristics. With its 83,534 $\mathrm{km}^{2}$ French Guiana is the largest French overseas territory in the Americas representing 15\% of the area of Mainland France, on par with Portugal, England or South Carolina. Population density is very low at 2.9 inhabitants $/$ per $\mathrm{km}^{2}$, with marked heterogeneity, most of the population living along the coastline and the remaining living in small villages scattered in the interior. French Guiana has a very high population growth, 5 times that of mainland France, a growth rate which is the highest in Latin America, similar to that of Guatemala [12]. The population is thus very young, with $43 \%$ of the population aged younger than 20 years. The socioeconomic conditions of this French territory are 43\% lower than in Mainland France [13]. In 2013, the unemployment rate was $32.8 \%$ [14]. However, despite these figures, French Guiana still has the highest GDP per capita in Latin America. Regarding access to care, some medical or surgical specialties are missing on the territory (Thoracic surgery, Cardiac Surgery, Burn wards, medically assisted procreation...). French Guianese patients are thus often evacuated to mainland France or Martinique for specialized procedures. Whereas patients living along the coast have similar average durations for access to care than in Mainland France, delays in accessing care are an issue for persons living in the interior who require lengthy helicopter transfers [15].

\section{Methods}

\section{Population}

The study was conducted using data from the cohort of patients included in the REIN registry for end stage renal disease between Jan 1st 2011 and December 31st 2013 in French Guiana. The study population corresponded to patients receiving treatment for ESRD by either dialysis or renal transplantation followed in one of the five centers treating such patients in French Guiana.

Between 2011 and 2013 a very low proportion of patients with end stage renal disease actually had renal biopsy: $13.5 \%$ (10.86\% in 2011, $13 \%$ in 2012 , and $16.57 \%$ in 2013). However, the diagnosis was performed by nephrologists after a complete but non invasive evaluation (biology on blood and urine, kidney and abdominal ultrasounds, abdominal scanner, and sometimes angiography.)

The R.E.I.N. network was developed by the Agence de Biomedecine (a public structure involved in 4 activities: organ, tissue, or cell transplants, procreation, embryology and human genetics). R.E.I.N uses 2 tools, Diadem for dialysed patients and Cristal for transplanted patients.

The cohort is approved by the French Regulatory authorities CNIL (Commission Nationale de l'Informatique et des Libertés, authorisation $n^{\circ} 903,188$ ) and the CCTIRS (Comité Consultative sur le traitement de l'Information en matière de Recherche dans le domaine de la Santé, authorisation $n^{\circ} 03.149$ )

\section{Registry data}

The REIN (Réseau Epidémiologie et Information en Néphrologie) registry aims to describe the incidence and prevalence of end stage renal disease. It describes treatments, population characteristics, patient survival, and access to renal transplant. The registry aims to be exhaustive for patients with end stage renal disease. Research assistants compile clinical and para clinical data from medical records at the three sites dealing with patients with end stage renal disease in French Guiana. The registry includes mainland France and the overseas French territories which allows identifying epidemiologic differences and benchmarking.

The information collected upon inclusion included data on patient care structures and patient data including socio-demographic, initial renal disease, clinical state and the treatment modalities data. The patients were followed by the medical staff who prospectively collected events occurring during treatment, notably dialysis modality changes, transfer between structures, weaning, renal transplant attempts, and death.

Descriptive statistics on quantitative and qualitative variables were performed on prevalent and incident cases in 2011, 2012 and 2013. Pearson's chi2 and Student's t-test were used to compare groups. Comparisons between French Guiana, Mainland France and other French Territories was performed with age and sexstandardized rates using the direct standardization method (reference population France) to avoid distortions due to the different population age and sex structures. 
Data analysis was performed using STATA 11.1 (STATA Corp, College Station, Texas).

\section{Results}

From 2011 to 2013, 309 patients were included in the registry. Among these patients, there were 99 incidents cases of ESRD (respectively 32, 28, 39 in 2011, 2012 and 2013) and 3 persons returning from a renal transplant in 2011. Seventy-two patients were died (respectively 22, 23, 27 in 2011, 2012 and 2013), ten patients were weaned, eighteen received renal transplant and thirtyone patients were transferred to another French territory or lost to follow-up.

After standardization, French Guiana was one of the three French territories with the highest ESRD prevalence and incidence. In 2011, ESRD incidence was 294 patients per million inhabitants in French Guiana, after the Reunion island (incidence of 412 per million inhabitants). In 2012 and 2013 French Guiana was still part of the first three French territories with the highest incidence (Fig. 1). The global ESRD prevalence was 1553 per million inhabitants in 2011, also behind the Reunion island (2792 patients per million inhabitants). In 2012 and 2013, French Guiana was still the second French territory with the highest prevalence of dialysis-treated ESRD (Fig. 2).

Mean age of patients was 51 years at dialysis onset ( \pm 15.45). Dialyzed patients in French Guiana wereyounger than 65 years at dialysis treatment onset in $80.7 \%$ of cases, versus $38.4 \%$ of patients in mainland France over the three years, $p<0,0001$ (Table 1).

The sex ratio of dialyzed patients was $1.3 \mathrm{men} /$ woman whereas it was 1.5 in mainland France. For incident cases, in 2011, French Guiana was the only territory with a female biased sex ratio (0.9 men per woman).
Half of dialyzed patients in French Guiana (50\%) were not born in France. The two other most represented countries were Suriname (17.57\%) and Haït (16.55\%).

Of all patients included in the registry, the two most frequent underlying pathologies causing the nephropathies in patients with ESRD were high blood pressure (40.47\%) and diabetes mellitus (28.95\%). The main nephropathies of dialysis patients is presented for each year in Table 2 for French Guiana and for other French territories.

Overall, $91.9 \%$ had at least one co-morbidity or risk factor. High blood pressure was present in $95 \%$ of patients. Fig. 3 represents the 8 principal co-morbidities, which were present in more than $10 \%$ of patients.

Most patients had discovered ESRD at the onset of dialysis, and $65.1 \%$ ofpatients had required emergency dialysis. Among incident patients, $71.3 \%$ had initially emergency dialysis versus $33 \%$ in mainland France $(p<0.0000)$, (Table 1$)$.

Concerning the modalities of dialysis in the study, $68 \%$ of patients were dialyzed in a medically advanced center (Mainland France: 59.3\%, $p<0.016$ ) whereas 33\% were treated in an auto-dialysis center. Most patients were dialyzed through an arterioveinous fistula (81\% in French Guiana, 78.3\% in mainland France, $p<0.374)$. However, the first dialysis mostly used a catheter in French Guiana, $83.9 \%$ a higher proportion than in Mainland France (57\%), $p<0.001$, (Table 1 ). The mean weekly number of dialysis sessions was three and the mean duration per session was $4 \mathrm{~h}$, as reported in Mainland France.

\section{Transplanted and deceased patients}

From 2011 to 2013, eighteen patients received renal transplant, their mean age was $46.9 \pm 12.9$ years.

Seventy two patients died during this period, with a mean age at death of $65.3 \pm 13.9$ years. Most patients died at the hospital or in a private clinic (66.85\%), the rest died at home $(26.44 \%)$ or at the dialysis unit

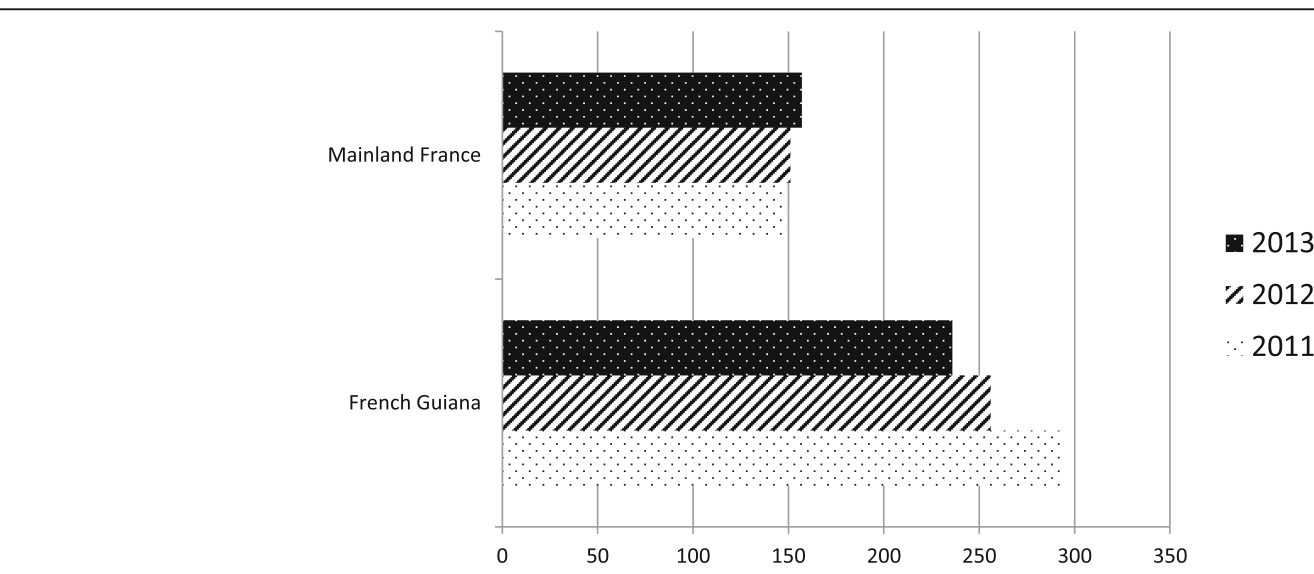

Fig. 1 Incidence of treated ESRD on December 31 of each year (standardized rates per million populations) in French Guiana and Mainland France [40] 


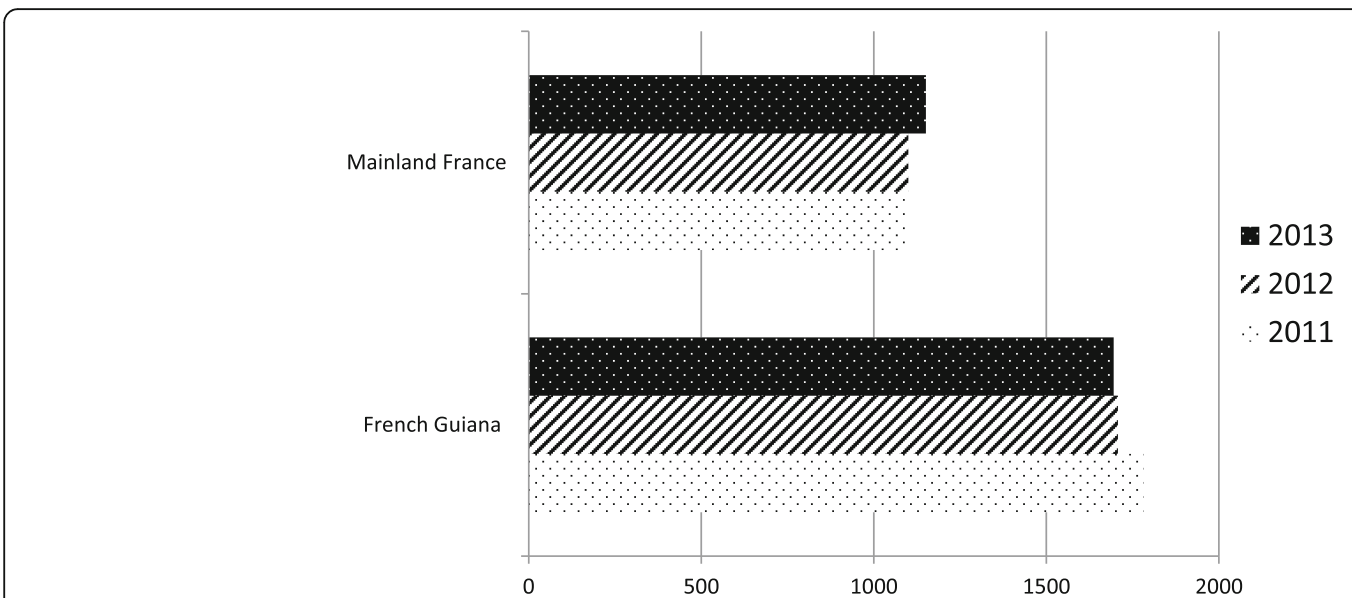

Fig. 2 Prevalence of treated ESRD on December 31 of each year (standardized rates per million populations) in French Guiana and Mainland France [40]

(5.47\%). The two most frequent causes of death were cerebrovascular and cardiovascular disease.

\section{Discussion}

Because of its location in the Amazon basin, French Guiana is more notorious for its infectious diseases than for its chronic diseases. However, the present results show that it is one the French territories that is most affected by ESRD. According to the cohort data, the epidemiologic profile of patients with ESRD was different from patients in mainland France. These differences were demographic (younger population, more women, half were migrants) but also regarding the initiation of care (mostly in emergency, using a catheter for the first dialyses).

The profile of patients dialysed in French Guiana resembled more what is observed in the Caribbean, or in Latin America, than in mainland France. In these regions, the mean age at the time of diagnosis of ESRD ranged from 47 years (in Jamaica) to 57 years (British Virgin Islands) $[3,4,16]$. The feminization of this pathology was observed in incident cases in French Guiana and in the Reunion Island [17]. This is presumably linked to the fact that, in these territories, diabetes mellitus affects more women than men, in contrast with mainland France.
In the Caribbean and in Latin America, diabetes mellitus and high blood pressure are the principal initial causes of nephropathy. In Latin America, half of the patients with high blood pressure at the time of diagnosis ESRD were not aware of having hypertension [4], underscoring the problem of early diagnosis of these causes of renal disease. In French Guiana, almost all patients in the registry had high blood pressure and nearly half had a hypertensive nephropathy, which is over the double of what is observed in mainland France. Moreover, African ancestry has been shown to be related to increased prevalence of hypertension and a greater fragility of target organs to hypertension when compared with Caucasians [18-20]. Regarding diabetes mellitus, the second comorbidity in our cohort, it has been shown that there are more treated cases of diabetes mellitus in the French overseas territories of the Americas than in mainland France, but that the results in term of glycemic control were not as good as in mainland France [21, 22]. Several studies have also shown that afro-caribbean and indo-asian ancestry were associated with a greater prevalence of diabetes mellitus and thus was associated with a greater risk of chronic renal failure [22-24]. AfroCaribbean populations, largely represented in French Guiana, are thus more likely to develop hypertension

Table 1 Comparisons between French Guiana and Mainland France

\begin{tabular}{|c|c|c|c|}
\hline & French Guiana & Mainland France & P \\
\hline Patients <65 years old \% $(n)$ & $80.7(185)$ & $38.4(40889)$ & $\leq 0.001$ \\
\hline Sex ratio & $1.3(185)$ & $1.5(40889)$ & \\
\hline Dialysis emergency \% (n) & $71.3(99)$ & $33(9115)$ & $\leq 0.001$ \\
\hline Dialysis in an advanced medical center \% (n) & $68(185)$ & $59.3(37032)$ & 0.016 \\
\hline Initial vascular access with catheter \% (n) & $84(185)$ & $57(40940)$ & $\leq 0.001$ \\
\hline Arterioveinous fistula vascular access \% (n) & $81(185)$ & $78.3(34743)$ & 0.374 \\
\hline
\end{tabular}


Table 2 Initial nephropathies among prevalent ESRD cases in French Guiana and France (on December 31th of each given year) [40]

\begin{tabular}{|c|c|c|c|c|c|c|c|c|c|}
\hline \multirow[t]{2}{*}{ Initial nephropathies } & \multicolumn{3}{|c|}{ French Guiana $n(\%)$} & \multicolumn{3}{|l|}{ France $n(\%)$} & \multicolumn{3}{|l|}{$p$-value } \\
\hline & 2011 & 2012 & 2013 & 2011 & 2012 & 2013 & 2011 & 2012 & 2013 \\
\hline $\begin{array}{l}\text { Nephroangiosclerosis with renal failure } \\
\text { (hypertensive nephropathy) }\end{array}$ & $88(47.8)$ & $85(47.75)$ & $82(43.16)$ & $8718(22.3)$ & $9301(22.7)$ & 9725 (22.9) & $<0.0000$ & $<0.0000$ & $<0.0000$ \\
\hline $\begin{array}{l}\text { Mesangial diffuse or nodular diabetic } \\
\text { nephropathy }\end{array}$ & $42(22.8)$ & $38(21.35)$ & $49(25.79)$ & 8181 (20.9) & 8737 (21.3) & $9152(21.5)$ & 0.76 & 0.99 & 0.47 \\
\hline
\end{tabular}

and diabetes mellitus, the two main causes of chronic renal failure [25-27].

There are however other specificities to French Guiana than its ethnic mix. The emergency context of initial care of ESRD had been observed in mainland France for several years, however in French Guiana, this delay before care was even greater Seven out of 10 patients had initiated dialysis in an emergency context in French Guiana versus three out of ten patients in mainland France. Several countries have emphasized that initial care in an emergency context was associated with complications, increased hospital stay, a reduction in autonomy and increased mortality in the first month of dialysis [28-30]. The present results raise the problem of early diagnosis and care of risk factors of ESRD, like in Latin America [3]. The early implementation of therapeutic recommendations for diabetes mellitus [31], and hypertension [31,32], have shown to improve the progression of renal disease. The "practice guidelines for chronic kidney diseases" recommend a practical clinical action plan for each patient based on the stage of his disease [33]. Early detection by routinely controlling marquers of renal disease is important $[33,34]$ to reduce the proportion of patients with a late diagnosis of renal disease. Systematic screening for comorbidities such as high blood pressure or diabetes mellitus seem like effective strategies to delay or even prevent the need for dialysis. The lack of nephrologists and diabetologists in French Guiana could also explain the treatment delay. Indeed, a demographic study in France showed that regions with a low density of nephrologists were those where the proportion of renal failure patients was highest [35]. Patient care would also improve if first line health care professionals and specialists in dialysis centers were better coordinated [2, 30, 36-38] to avoid late referral, which is associated with increased mortality after the initiation of dialysis [33]. Overall, given the scarcity of nephrologists in French Guiana, organisational efforts are needed to implement coordinated multisectoral care of patients. Although, there were no data on socioeconomic level and access to rights and access to care, the progression of high blood pressure or diabetes mellitus towards complications may reflect delayed access to care for the more vulnerable segment of the population in French Guiana [15, 39]. Disentangling what results from disorganization and low numbers of health practitionner, from patient's representations and health seeking behaviours and

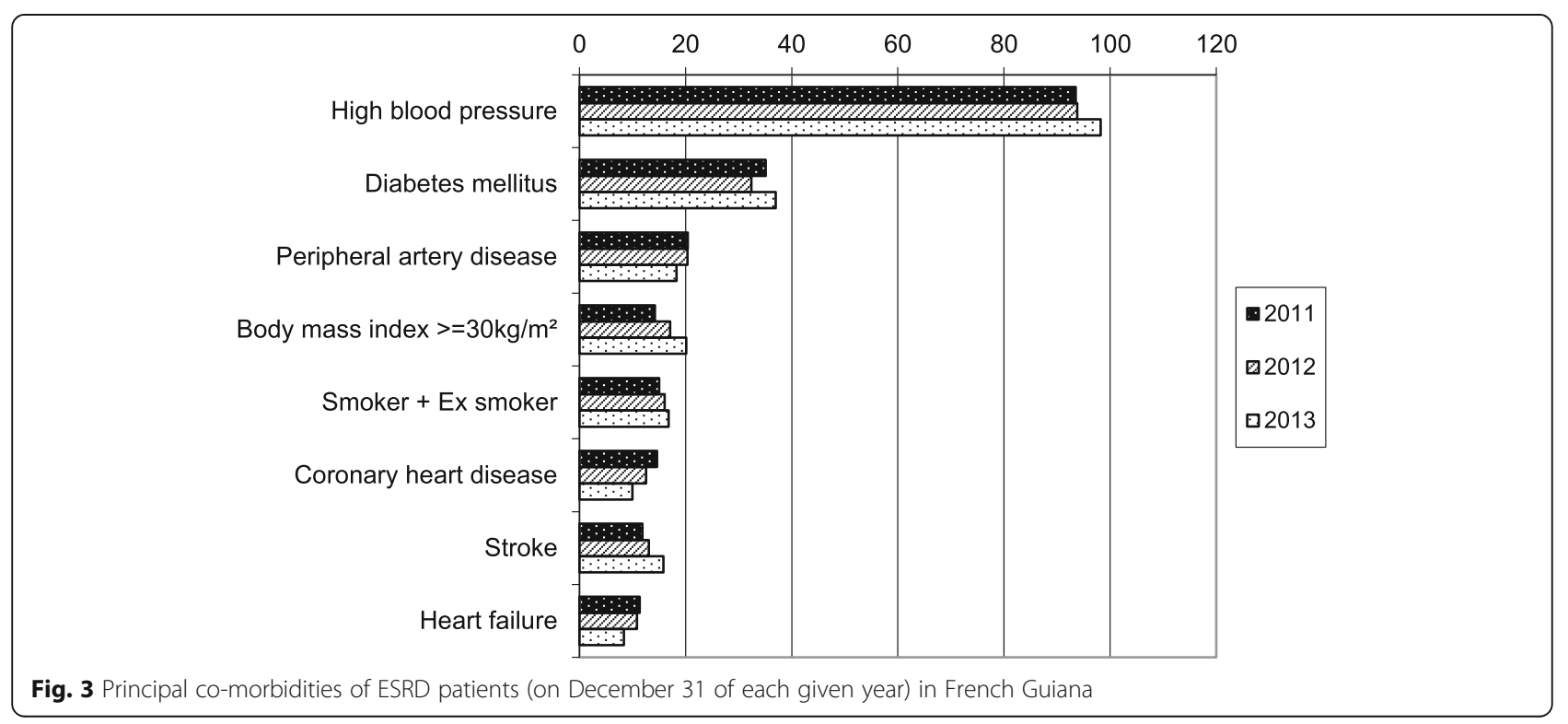


from true obstacles to care is an important research question that may guide future interventions to improve these preoccupying figures.

\section{Conclusion}

In France, French Guiana is perceived as a hostile territory still struggling with numerous tropical diseases. However, the epidemiologic transition from infectious diseases to chronic diseases is now quite apparent in the local burden of disease. Whereas infectious diseases specialists are drawn to the challenges of this" tropical medicine hotspot", the rising problem of chronic diseases fails to do so despite important needs and a lack of specialized professionals. The first results of the end stage renal disease registry in French Guiana give important public health informations: i) it shows the high prevalence of end stage renal disease in this territory ii) it shows the atypical profile of patients and the late access to care which are closer to Caribbean or south American patient characteristics. It would also be important to adapt public health measures to the local epidemiology and notably improve access to care and early management of the main causes of renal failure in French Guiana.

\section{Abbreviations \\ ATIRG: Association Traitement de l'Insuffisance Rénale en Guyane; CCTIRS: Comité Consultative sur le Traitement de I'Information en matière de Recherche dans le domaine de la Santé; CNIL: Commission Nationale de I'Informatique et des Libertés; ESRD: End-stage renal disease; HIV: Human Immunodeficiency Virus; R.E.I.N: Renal Epidemiology and Information Network registry}

\section{Acknowledgements}

We acknowledge all registry participants, especially the staff of dialysis centres in French Guiana: Kapa santé Clinique Véronique, Association Traitement de l'Insuffisance Rénale en Guyane (ATIRG) and Centre the hospital Andrée Rosemon Cayenne.

\section{Funding}

The REIN registry is funded by "Agence de la Biomedecine (ABM)".

\section{Availability of data and materials}

Under French law the anonymized data can only be available if the French regulatory authority Commission Nationale Informatique et Libertés CNIL gives permission to exchange data. This will require making a request to the CNIL at the following address: 3 Place de Fontenoy - TSA 80715-75,334 PARIS CEDEX 07.

\section{Authors' contributions}

DRR wrote the article, has coordinated the registry has collected the data, has conducted statistical analysis and interpretation of data. MM assisted in the collection of patient data and validation of medical records. RR assisted in the collection of patient data and validation of medical records. CC has helped coordinate the register at national level and data acquisition MN participated in the critical revision of the intellectual content of the manuscript and gave final approval of the version to be published. CB has participated in the critical revision of the intellectual content of the manuscript and gave final approval of the version to be published. All authors read and approved the final manuscript

\section{Competing interests}

The authors declare that they have no competing interests.

\section{Consent for publication}

Not applicable.

\section{Ethics approval and consent to participate}

All patients included gave informed verbal consent. Ethics committees: Ethics approvals references were CNIL (Comité Nationale de l'Informatique et des Libertés) n903,188 and CCTIRS (Comité Consultatif sur le Traitement de I'Information en matière de Recherche dans le domaine de la Santé) $n^{\circ}$ 03.149. The Clinical Investigation Center CIC INSERM 1424 is responsible for the REIN registry in French Guiana and is therefore authorize to use the data.

\section{Publisher's Note}

Springer Nature remains neutral with regard to jurisdictional claims in published maps and institutional affiliations.

\section{Author details}

${ }^{1}$ Centre d'Investigation Clinique Epidémiologie Clinique Antilles Guyane CIC INSERM 1424, Centre hospitalier Andrée Rosemon, Rue des flamboyants BP 6006, 97306 Cayenne, French Guiana. ${ }^{2}$ KAPA santé, Clinique Véronique, 1453 rte Baduel, 97300 Cayenne, French Guiana. ${ }^{3}$ Association Traitement de I'Insuffisance Rénale en Guyane (ATIRG), Centre hospitalier Andrée Rosemon, 1361 rte Baduel, 97300 Cayenne, French Guiana. ${ }^{4}$ Biomedecine Agency, La plaine-Saint Denis France, 1 avenue du Stade de, 93212 Saint-Denis La Plaine, France. ${ }^{5}$ EA3593, UFR Médecine - Université des Antilles et de la Guyane, Cayenne, French Guiana.

Received: 17 May 2016 Accepted: 8 June 2017

Published online: 30 June 2017

\section{References}

1. Coresh J, Byrd-Holt D, Astor BC, Briggs JP, Eggers PW, Lacher DA, et al. Chronic kidney disease awareness, prevalence, and trends among U.S. adults, 1999 to 2000. J Am Soc Nephrol. 1 janv 2005;16(1):180-188.

2. Lang P. Insuffisance rénale chronique: trop souvent, trop tard. Presse Med. 2006;35(1):9-10.

3. Rodriguez-Iturbe B, Bellorin-Font E. End-stage renal disease prevention strategies in Latin America. Kidney Int. 2005;68:S30-6.

4. Soyibo AK, Barton EN. Reporte del registro renal del Caribe, 2006. West Indian Med J. 2007:56(4):355-63.

5. Kessler M, Ayav C, Erpelding M-L, Couchoud C. Évolution des caractéristiques des patients en insuffisance rénale chronique terminale lors de l'initiation du traitement par dialyse. Données de REIN 2004-2009. Néphrologie Thérapeutique. déc 2012;8(7):521-526.

6. Conan C. Les patients diabétiques traités en Guyane. Antiane 2008-09,70:3031 [cité 16 déc 2015]; Disponible sur: http://www.epsilon.insee.fr/jspui/ handle/1/11199.

7. Inamo J, Malfatti S, Lang T, Atallah A, Inamo A, Larabi L, et al. [Arterial hypertension in the French Caribbean regions: gender related differences]. Arch Mal Coeur Vaiss. août 2005;98(7-8):845-849.

8. Accidents vasculaires cérébraux (AVC) [Internet]. [cité 16 déc 2015]. Disponible sur: http://www.ars.guyane.sante.fr/Accidents-vasculairescerebrau.146416.0.html

9. Adler Al, Stevens RJ, Manley SE, Bilous RW, Cull CA, Holman RR. Development and progression of nephropathy in type 2 diabetes: the United Kingdom prospective diabetes study (UKPDS 64). Kidney Int. 2003; 63(1):225-32.

10. Choi Al, Rodriguez RA, Bacchetti P, Volberding PA, Havlir D, Bertenthal D, et al. Low rates of antiretroviral therapy among HIV-infected patients with chronic kidney disease. Clin Infect Dis. 15 déc 2007:45(12):1633-1639.

11. Szczech LA, Gupta SK, Habash R, Guasch A, Kalayjian R, Appel R, et al. The clinical epidemiology and course of the spectrum of renal diseases associated with HIV infection. Kidney Int. 2004;66(3):1145-52.

12. Insee Guyane. Insee - Économie - Comptes définitifs 2010 Guyane [Internet]. Compte définitifs 2010 Guyane insee flash n 14 avril 2015. [cité 9 sept 2016] Disponible sur: http://www.insee.fr/fr/themes/document.asp?reg_id=25\&ref_ id $=22437$

13. Marcelle J-R, Clarence P. Insee - Revenus-Salaires - Enquête Budget de famille 2011 - Le niveau de vie des ménages guyanais augmente mais les inégalités s'accroissent [Internet]. Insee Analyses Guyane n¹1 aout 2015. [cité 6 sept 2016]. Disponible sur: http://www.insee.fr/fr/themes/document. asp?reg_id $=25 \&$ ref_id $=23314$ 
14. Insee - Département de La Guyane (973) - Dossier complet [Internet]. [cité 7 sept 2016]. Disponible sur: http://www.insee.fr/fr/themes/dossier_complet. asp?codgeo=DEP-973

15. Hélène DUPLAN, Benoit HURPEAU. Insee - Santé - Accès aux soins hospitaliers en Guyane : derrière un constat encourageant, de fortes disparités. Insee Anal Guyane [Internet]. 2014 [cité 23 déc 2015];(2). Disponible sur: http://www.insee. $\mathrm{fr} / \mathrm{fr} /$ themes/document.asp?reg_id=25\&ref_id=21717

16. Sesso RC, Lopes AA, Thomé FS, Lugon JR, Santos DR. 2010 report of the Brazilian dialysis census. J Bras Nefrol. déc 2011;33(4):442-447.

17. Bauduin B. L'insuffisance rénale chronique à la Réunion_2011.pdf [Internet]. [cité 16 déc 2015]. Disponible sur: http://www.aurar-dialyse.fr/IMG/pdf/irc_ 2011_rapport_ors.pdf.

18. Sheats N, Lin Y, Zhao W, Cheek DE, Lackland DT, Egan BM. Prevalence, treatment, and control of hypertension among African Americans and Caucasians at primary care sites for medically under-served patients. Ethn Dis. 2005;15(1):25-32.

19. Inamo J, Atallah A, Ozier-Lafontaine N, Inamo A, Larabi L, Gaudemaris Rd. Existe-t-il des spécificités dans la prévalence et la prise en charge de I'hypertension artérielle aux Antilles-Guyane par rapport à la France métropolitaine ? Bull Épidémiologique Hebd. 2008;(49-50):489-92. Disponible sur: http://opac.invs.sante.fr/index.php?|vl=notice_display\&id= 1725 .

20. Steichen O. Hypertension artérielle du sujet noir. Prévalence. 2010;20:25.

21. Ndong JR, Romon I, Druet C, Prevot L, Hubert Brierre R, Pascolini E, et al. Caractéristiques, risque vasculaire, complications et qualité des soins des personnes diabétiques dans les départements d'outre-mer et comparaison à la métropole : Entred 2007-2010, France [Internet]. 2010. 432-6 p. Disponible sur: http://opac.invs.sante.fr/index.php?lvl=notice_display\&id=502

22. Fagour C, Sorel G, Inamo J, Couffinhal T. Anomalies du métabolisme glucidique au décours d'un syndrome coronarien aigu : une étude comparative de deux groupes ethniques français. Ann Endocrinol. nov 2008;69(5):433-439.

23. Prasad S, Singh S, Duncan N, Cairns TD, Griffith M, Hakim N, et al. Ethnicity and survival on dialysis in west London. Kidney Int. 2004;66(6):2416-21.

24. Xue JL, Egge PW, Agodoa LY, Foley RN, Collins AJ. Longitudinal study of racial and ethnic differences in developing end-stage renal disease among aged Medicare beneficiaries. J Am Soc Nephrol. 1 avr 2007;18(4):1299-1306.

25. Albitar S, Bourgeon B, Genin R, Schohn D, Fen-Chong M, Serveaux MO, et al. Epidemiology of end-stage renal failure in Reunion Island (results from the registry of the Indian Ocean Society of Nephrology). Nephrol Dial Transplant. 1998;13(5):1143-5.

26. Cordonnier DJ, Zmirou D, Benhamou PY, Halimi S, Ledoux F, Guiserix J. Epidemiology, development and treatment of end-stage renal failure in type 2 (non-insulin-dependent) diabetes mellitus. Diabetologia. 1993;36(10): $1109-12$.

27. Blanchet Deverly A, Kangambega P, Hue K, Donnet J-P, Merault H, Foucan L. Left ventricular hypertrophy in hypertensive type 2 diabetic patients according to renal function. Diabetes Metab. sept 2009;35(4):280-286.

28. Hoffmann M, Binaut R, Maisonneuve N, Bacri J-L, Fleury D, Vanhille P, et al. Suivi néphrologique et niveau de prise en charge des patients en insuffisance rénale terminale. Néphrologie Thérapeutique. févr 2006;2(1):15-23.

29. Laville M, Juillard L, Deléaval P, Favé S, Charlois A-L, Touzet S. Rôle des réseaux de santé dans le dépistage et la prise en charge de la maladie rénale chronique. Presse Med. déc 2007;36(12):1865-1874.

30. Ledoux F, Rasamimanantsoa D, Moulin B, Hannedouche T. Des premiers symptômes à l'insuffisance rénale terminale: nécessité du suivi néphrologique. Rev Médecine Interne. 2001;22(3):245-54.

31. Frimat L, Loos-Ayav C, Panescu V, Cordebar N, Briançon S, Kessler M. Early referral to a nephrologist is associated with better outcomes in type 2 diabetes patients with end-stage renal disease. Diabetes Metab. févr 2004; 30(1):67-74.

32. Atallah A, Kelly-Irving M, Ruidavets J-B, de Gaudemaris R, Inamo J, Lang T. Prévalence et prise en charge de l'hypertension artérielle en Guadeloupe. France Bull Épidémiologique Hebd. 2008:49-50.

33. Levey AS, Coresh J, Balk E, Kausz AT, Levin A, Steffes MW, et al. National Kidney Foundation practice guidelines for chronic kidney disease: evaluation, classification, and stratification. Ann Intern Med. 15 juill 2003; 139(2):137-147.

34. Parmar MS. Chronic renal disease. BMJ. 13 juill 2002;325(7355):85-90.

35. Nivet $H$, Maingourd C, Mignon F. Démographie des néphrologues en France en 2002. Nephrologie. 2003;24(8):431-6.
36. Montagnac R, Vitry F, Schillinger F. Prise en charge par hémodialyse des patients octogénaires. Néphrologie Thérapeutique. 2007;3:249-62.

37. Jungers P, Joly D, Nguyen-Khoa T, Mothu N, Bassilios N, Grünfeld J-P. Continued late referral of patients with chronic kidney disease. Presse Med. 2006;35(1-C1):17-22.

38. Hanset M. L'insuffisance rénale chronique. Le dépistage par le médecin généraliste. Rev Médicale Brux. 2007;28(5):465-8.

39. Conan Claude, Fery Philippe. Insee - Santé - L'assurance maladie en Guyane : les ruptures des droits de base. Antiane. juill 2011;(74):43-44

40. Cécile C, Mathilde L, Prada-Bordenave E, Jacquelinet C, et al. Rapport annuel 2011 réseau Epidemiologique et Information en Néphrologie. Néphrologie Thérapeutique. 2012;8:S1.

\section{Submit your next manuscript to BioMed Central and we will help you at every step:}

- We accept pre-submission inquiries

- Our selector tool helps you to find the most relevant journal

- We provide round the clock customer support

- Convenient online submission

- Thorough peer review

- Inclusion in PubMed and all major indexing services

- Maximum visibility for your research

Submit your manuscript at www.biomedcentral.com/submit 